\title{
PENGARUH KEPUASAN KERJA TERHADAP ORGANIZATIONAL CITIZENSHIP BEHAVIOR DENGAN KOMITMEN ORGANISASI SEBAGAI VARIABEL MEDIASI
}

\author{
Arum Darmawati \\ Email: arum_d@yahoo.com \\ Maagement School of Yogyakarta State University
}

\section{Abstract}

Tujuan penelitian ini untuk memperoleh gambaran mengenai tingkat kepuasan kerja, komitmen organisasi serta OCB yang ada di UNY. Penelitian ini menggunakan pendekatan kuantitatif. Hasil penelitian menunjukkan bahwa kepuasan kerja dan komitmen organisasi memiliki pengaruh yang positif dan signifikan terhadap variabel kepuasan kerja karyawan UNY. Komitmen organisasi memediasi pengaruh kepuasan kerja dengan OCB karyawan UNY. Tingkat kepuasan kerja, komitmen organisasi dan tingkat $O C B$ karyawan UNY masuk dalam kategori tinggi tinggi.

Keywords: Kepuasan Kerja, organizational behavior citizenship, komitmen organisasi

\section{A. Latar Belakang}

Saat ini, Indonesia menghadapi ASEAN Economic Community (AEC). AEC tentunya menuntut perusahaan-perusahaan Indonesia untuk berkompetisi, karena perusahaan tidak hanya dihadapkan pada persaingan dengan perusahaan dalam negeri saja, tetapi juga dengan perusahaan luar negeri. Menghadapi situasi dan kondisi tersebut, perusahaan harus menentukan strategi dan kebijakan manajemen yang tepat, khususnya dalam pengembangan sumberdaya manusia (SDM). Pengelolaan SDM saat ini merupakan suatu keharusan dan bukan lagi merupakan suatu pilihan apabila perusahaan ingin survive. 
SDM merupakan hal yang sangat penting dalam suatu organisasi, karena keefektifan dan keberhasilan suatu organisasi sangat tergantung pada kualitas dan kinerja sumber daya manusia yang ada pada organisasi tersebut. Kinerja sumber daya manusia (karyawan) yang tinggi akan mendorong munculnya organizational citizenship behavior (OCB), yaitu perilaku melebihi apa yang telah distandarkan perusahaan (Krietner, 2004).

OCB dapat timbul dari berbagai faktor dalam organisasi, di antaranya karena adanya kepuasan kerja dari karyawan dan komitmen organisasi yang tinggi (Robbins dan Judge, 2007). Ketika karyawan merasakan kepuasan terhadap pekerjaan yang dilakukannya, maka karyawan tersebut akan bekerja secara maksimal dalam menyelesaikan pekerjaannya, bahkan melakukan beberapa hal yang mungkin diluar tugasnya. Begitu juga dengan ketika seseorang mempunyai komitmen yang tinggi terhadap organisasinya, maka orang tersebut akan melakukan apapun untuk memajukan perusahaannya karena keyakinannya terhadap organisasinya (Luthan, 2000). Lebih lanjut, Karim dan Rehmen (2012) menemukan bahwa tingkat komitmen organisasi karyawan dipengaruhi oleh kepuasan kerja yang dirasakan katyawan, artinya semakin puas seorang karyawan, maka semakin tinggi komitmen organisasinya.

Walaupun masih jarang, tetapi munculnya OCB menjadi hal yang positif bagi perusahaan, tak terkecuali di Universitas Negeri Yogyakarta (UNY) yang sedang menuju world class university (WCU). Proses menjadi WCU menjadi tantangan tersendiri bagi UNY. Hal ini tentu membawa dampak pada pemeliharaan maupun peningkatan kinerja UNY, baik peningkatan kualitas tenaga pengajar (dosen), tenaga administrasi (karyawan), maupun mahasiswanya. Munculnya 
OCB dapat menjadi gambaran adanya kinerja yang tinggi dalam organisasi, karena OCB merupakan perilaku yang beyond expectation.

UNY pada awalnya bernama Institut Keguruan dan Ilmu Pendidikan (IKIP), yang kemudian pada tahun 1999 berubah menjadi Universitas Negeri Yogyakarta. Pergantian nama ini memberikan dampak yang signifikan pada organisasi tata kelola di UNY. Fakultas yang dulu menggunakan kata pendidikan, berubah menjadi fakultas murni, yang di dalamnya tersiri dari prodi kependidikan maupun non kependidikan. Perubahan tersebut tentu saja berdampak pada pengelolaan SDM yang ada di UNY. Pengelolaan SDM sangat diperlukan guna memanfaatkan potensi SDM yang dimiliki UNY. Kinerja karyawan UNY menjadi bagian dari pengelolaan SDM di UNY.

Walaupun sudah baik, akan tetapi ada beberapa masalah yang berkaitan dengan kinerja karyawan UNY yang masih dirasa kurang. Hal ini dapat terlihat dari kedisiplinan jam kehadiran, keramahan dalam melayani stakeholder, maupun dalam hal kehadiran. Kinerja yang kurang baik akan semakin sulit memunculkan OCB dalam organisasi. OCB dipengaruhi oleh banyak faktor. Sesen, Harun dan Basim Nejed (2012) menyatakan bahwa OCB dipengaruhi oleh kepuasan kerja dan komitmen organisasi.

Ketika seseorang mendapatkan kepuasan kerja dan mempunyai komitmen yang tinggi terhadap organisasi, karyawan akan memberikan pelayanan yang baik dan begitu juga sebaliknya, ketika karyawan saja tidak mengalami kepuasan maka pelayanan yang diberikan kepada konsumen, dalam hal ini mahasiswa, dosen atau pihak luar perusahaan; bisa tidak memuaskan. Kepuasan kerja diartikan sebagai tanggapan emosional seseorang terhadap aspekaspek di dalam atau pada keseluruhan pekerjaannya (Nawawi, 2003). Keadaan emosional atau sikap seseorang tersebut akan diperlihatkan 
dalam bentuk tanggungjawab, perhatian, serta perkembangan kinerjanya.

Tujuan penelitian ini yaitu untuk memperoleh gambaran mengenai tingkat kepuasan kerja, komitmen organisasi serta OCB yang ada di UNY. Berkaitan dengan hasil penelitian ini diharapkan secara teoritis dapat dimanfaatkan sebagai media yang andal untuk konfirmasi terhadap perubahan yang nyata pada paradigma yang berlaku dan dapat memperkuat, membedakan, atau menolak hasil temuan pada paradigma lama. Secara praktis hasil penelitian ini dapat membantu jajaran pimpinan lembaga UNY dalam proses pengambilan keputusan yang berkaitan dengan karyawannya

\section{Kajian Pustaka}

\section{A. Organizational Citizenship Behavior}

Menurut Organ dan Ryan (1994), organizational citizenship behavior adalah perilaku-perilaku yang dilakukan oleh anggota organisasi/karyawan yang: tidak secara tegas diberi penghargaan apabila mereka melakukannya dan juga tidak akan diberi hukuman apabila mereka tidak melakukannya, tidak merupakan bagian dari deskripsi pekerjaan yang dimiliki oleh karyawan, dan merupakan perilaku karyawan yang tidak membutuhkan latihan terlebih dahulu untuk melaksanakannya.

Menurut Sloat (1999), good organizational citizens adalah karyawan yang melakukan tindakan yang mengarah pada terciptanya keefektifan fungsi-fungsi dalam organisasi dan tindakan tindakan tersebut secara eksplisit tidak diminta (secara sukarela), serta tidak secara formal diberi penghargaan (dengan insentif). Dengan kata lain, $O C B$ merupakan perilaku yang selalu mengutamakan kepentingan orang lain, hal itu diekspresikan dalam tindakan-tindakan yang mengarah pada hal-hal yang bukan untuk memenuhi kepentingan pribadi, melainkan untuk mewujudkan kesejahteraan orang lain. 
Lovell (1999) berpendapat bahwa $O C B$ merupakan suatu perilaku yang memperluas dan melebihi dari perilaku apa saja yang telah disyaratkan oleh organisasi yang tertuang dalam suatu deskripsi pekerjaan yang formal (formal job description). Menurut Witt yang dikutip oleh Lovell, OCB menunjuk pada tindakan-tindakan yang dilakukan oleh karyawan melampaui peran yang telah disyaratkan oleh organisasi dan tindakan-tindakan tersebut memajukan kesejahteraan dari rekan kerja, kelompok kerja atau bahkan organisasi. Organisasi tergantung pada perilaku $O C B$ dari karyawan untuk membantu koleganya yang sedang mempunyai masalah, menciptakan suatu iklim kerja yang positif, dengan sabar menghadapi gangguan tanpa mengeluh dan menjaga asset yang dimiliki organisasi (Lovell, 1999).

Menurut Greenberg dan Baron (2003), $O C B$ adalah tindakan yang dilakukan anggota organisasi yang melebihi dari ketentuan formal pekerjaannya. Secara umum, ada tiga komponen utama $O C B$. Pertama, perilaku tersebut lebih dari ketentuan formal atau deskripsi pekerjaan yang telah ditentukan. Kedua, tindakan tersebut tidak memerlukan latihan (bersifat alami), dengan kata lain, orang melakukan tindakan tersebut dengan sukarela. Ketiga, tindakan tersebut tidak dihargai dengan imbalan formal oleh organisasi.

Organ dan Ryan dalam Greenberg dan Baron (2003), menyatakan bahwa ada lima dimensi dari $O C B$, yaitu:

a. Altruism (Helping), merupakan suatu hal yang terjadi ketika seorang karyawan memberikan pertolongan kepada karyawan lain untuk menyelesaikan tugas atau pekerjaannya dalam keadaan tertentu atau tidak seperti biasanya, misalnya ketika seorang karyawan habis sembuh dari sakitnya.

b. Conscientiousnes, mengacu pada seorang karyawan dalam mengerjakan tugas-tugas yang diberikan (dalam hal keperilakuan) dilakukan dengan cara melebihi atau di atas apa yang telah disyaratkan oleh organisasi/perusahaan.

c. Sportmanship (sikap sportif), erupakan suatu sikap yang lebih menekankan pada aspek-aspek positif organisasi daripada aspek negatif. Memberikan rasa toleransi terhadap gangguan gangguan pada pekerjaan, yaitu ketika 
seorang karyawan memikul pekerjaan yang tidak mengenakkan tanpa harus mengemukakan keluhan atau komplain.

d. Courtesy (kebaikan), Merupakan perilaku-perilaku baik, misalnya perilaku membantu seseorang mencegah terjadinya suatu permasalahan atau membuat langkah-langkah untuk meredakan atau mengurangi berkembangnya suatu masalah. Kebaikan (courtesy) menunjuk pada tindakan pengajaran kepada orang lain sebelum dia melakukan tindakan atau membuat keputusan yang berkaitan dengan pekerjaannya.

e. Civic Virtue, Merupakan tindakan yang dilakukan untuk ikut serta mendukung fungsi- fungsi administrasi organisasi. Perilaku yang dapat dijelaskan sebagai partisipasi aktif karyawan dalam hubungan keorganisasian, misalnya menghadiri rapat, menjawab surat-surat dan selalu mengikuti isu-isu terbaru yang menyangkut organisasi.

\section{B. Kepuasan Kerja}

Kepuasan kerja merupakan respon afektif atau emosional dari sebuah pekerjaan (Krieter \& Kinicki, 2004). Salah seorang bisa merasakan kepuasan di satu aspek dan di aspek yang lain. Robbins dan Judge (2007) menyatakan bahwa kepuasan kerja merupakan perasaan positif tentang suatu pekerjaan yang merupakan hasil evaluasi dari beberapa karakteristik.

Dari pengertian tersebut di atas, perasaan positif maupun negatif yang dialami karyawan menyebabkan seorang dapat mengalami kepuasan maupun ketidakpuasan kerja. Kepuasan/ketidakpuasan merupakan masalah yang kompleks, karena berasal dari berbagai elemen kerja, misalnya terhadap pekerjaan mereka sendiri, gaji/upah, promosi, supervisi, rekan kerja, ataupun pekerjaan yang dilakukannya secara keseluruhan. Dari berbagai penelitian yang telah banyak dilakukan, ketika karyawan ditanya tentang respon dari pekerjaan yang telah mereka lakukan, hasilnya bervariasi untuk berbagai elemen kerja, Dari hasil penelitian, secara umum karyawan merasakan kepuasan secara keseluruhan (Robbins dan Judge, 2007). 
Dalam pekerjaan, banyak sekali elemen yang berpengaruh terhadap kepuasan dan ketidakpuasan. Seseorang dapat mengalami kepuasan untuk satu elemen pekerjaan, tetapi tidak untuk elemen pekerjaan yang lain. Elemen-elemen pekerjaan itu adalah: pekerjaan mereka sendiri, gaji/upah, promosi, supervisi, rekan kerja, dan pekerjaan secara keseluruhan.

Krieter \& Kinicki (2004) menyatakan bahwa faktor yang menyebabkan kepuasan dan tidakkupuasan adalah: pemenuhan kebutuhan, pencapaian tujuan, deviasi dari yang seharusnya diterima dengan yang didapatkan, dan keadilan.

Menurut Teori Herzberg, terdapat dua faktor yang menyebabkan kepuasan dan ketidakpuasan, yaitu:

a. Faktor Motivator merupakan karakteristik pekerjaan berkaitan dengan kepuasan pekerjaan, yaitu sejumlah kebutuhan yang apabila dipenuhi akan menimbulkan kepuasan tetapi jika tidak dipenuhi akan mengurangi kepuasan

b. Faktor Hygiene merupakan karakteristik pekerjaan berkaitan dengan ketidakpuasan pekerjaan, yaitu sejumlah kebutuhan yang apabila dipenuhi tidak akan meningkatkan motivasi, tetapi jika tidak dipenuhi akan menimbulkan kepuasan.

Faktor yang termasuk dalam faktor motivator adalah prestasi kerja, promosi, tanggungjawab, pengakuan, dan kerja itu sendiri. Sedangkan faktor yang termasuk hygiene faktor adalah hubungan antar pribadi, keamanan kerja, kehidupan pribadi, keamanan kerja, kebijakan administrasi, gaji, status, supervisi, dan kondisi kerja.

Baik faktor motivator dan faktor hygiene sangat penting bagi pemeliharaan tingkat kepuasan pegawai. Kedua faktor ini selalu berjalan seiring dengan aktivitas kerja seseorang dalam organisasinya. 


\section{Komitmen Organisasi}

Komitmen organisasi adalah suatu keadaan dimana seseorang karyawan memihak organisasi tertentu serta tujuan tujuan dan keinginannya untuk mempertahankan keanggotaan dalam organisasi tersebut. Robbins dan Judge (2007) didefinisikan sebagai keterlibatan pekerjaaan yang tinggi berarti memihak pada pekerjaan tertentu seseorang individu. Komitmen organisasional yang tinggi berarti memihak organisasi yang merekrut individu tersebut. Dalam organisasi sekolah guru merupakan tenaga profesional yang berhadapan langsung dengan siswa, maka guru dalam menjalankan tugasnya sebagai pendidik mampu menjalankan berbagai kebijakan dengan tujuan-tujuan tertentu dan mempunyai komimen yang kuat terhadap tempat dia bekerja.

Menurut Griffin (2004), komitmen organisasi adalah sikap yang mencerminkan sejauh mana seseorang individu mengenal dan terikat pada organisasinya. Seseorang individu yang memiliki komitmen tinggi kemungkinan akan melihat dirinya sebagai anggota sejati organisasi. Menurut Luthans (1995), komitmen organisasi didefinisikan sebagai: keinginan kuat untuk tetap sebagai anggota organisasi tertentu; , keinginan untuk berusaha keras sesuai keinginan organisasi; dan keyakinan tertentu, dan penerimaan nilai dan tujuan organisasi.

Dengan kata lain, ini merupakan sikap yang merefleksikan loyalitas karyawan pada organisasi dan proses berkelanjutan di mana anggota organisasi mengekspresikan perhatiannya terhadap organisasi dan keberhasilan serta kemajuan yang berkelanjutan

Allen dan Mayer dalam Greenberg dan Baron (2003) mengemukakan tiga dimensi komitmen organisasi sebagai berikut:

a. Komitmen afektif (affective comitment):

Mengacu pada keterikatan emosional, identifikasi serta keterlibatan seorang karyawan pada suatu organisasi. Komitmen afektif 
seseorang akan menjadi lebih kuat bila pengalamannya dalam suatu organisasi konsisten dengan harapan-harapan dan memuaskan kebutuhan dasarnya dan sebaliknya.

Komitmen afektif menunjukkan kuatnya keinginan seseorang untuk terus bekerja bagi suatu organisasi karena ia memang setuju dengan organisasi itu dan memang berkeinginan melakukannya. Pegawai yang mempunyaikomitmen afektif yang kuat tetap bekerja dengan perusahaan karena mereka menginginkan untuk bekerja di perusahaan itu.

b. Komitmen berkelanjutan (continuence commitment):

Komitmen berdasarkan kerugian yang berhubungan dengan keluarnya karyawan dari organisasi. Hal ini mungkin karena kehilangan senioritas atas promosi atau benefit. Konsep side-bets orientation yang menekankan pada sumbangan seseorang yangsewaktu-waktu dapat hilang jika orang itu meninggalkan organisasi. Tindakan meninggalkan organisasi menjadi sesuatu yang beresiko tinggi karena orang merasa takut akan kehilangan sumbangan yang mereka tanamkan pada organisasi itu dan menyadari bahwa mereka tak mungkin mencari gantinya.

c. Komitmen normatif (normative commiment):

Komitmen normatif berkaitan dengan perasaan wajib untuk tetap berada dalam organisasi karena memang harus begitu; tindakan tersebut merupakan hal benar yang harus dilakukan.

Kepuasan kerja dan komitmen organisasi yang dirasakan oleh karyawan akan mampu membuat karyawan berperilaku OCB. Seorang karyawan yang merasakan kepuasan kerja akan bersedia melakukan apapun untuk perusahaan yang pada akhirnya menimbulkan OCB. OCB juga akan timbul ketika seorang karyawan memiliki komitmen yang tinggi 
terhadap organisasi, sedangkan komitmen organisasi itu dapat muncul ketika seseorang itu merasakan kepuasan kerja. Karyawan yang puas terhadap pekerjaannya akan memiliki komitmen yang tinggi terhadap organisasinya, yang pada akhirnya mengarah pada OCB

Berbagai penelitian telah dilakukan berkaitan dengan kepuasan, komitmen organisasi dan OCB. Penelitian Sesen, Harun dan Basim Nejed (2012), menemukan bahwa kepuasan kerja dan komitmen organisasi berpengaruh terhadap $\mathrm{OCB}$, dan komitmen organisasi menjadi variabel yang memediasi pengaruh kepuasan kerja terhadap OCB. Seniati (2006) dan Karim dan Rehman (2012), menemukan bahwa kepuasan kerja, berpengaruh terhadap komitmen organisasi.

Berdasarkan kajian pustaka dan penelitian terdahulu yang relevan, maka dapat dibuat hipotesis sebagai berikut:

$\mathrm{H}_{1}$ : Kepuasan kerja berpengaruh positif terhadap $O C B$

$\mathrm{H}_{2}$ : Komitmen organisasi berpengaruh positif terhadap $O C B$

$\mathrm{H}_{3}$ : Komitmen organisasi memediasi pengaruh kepuasan kerja dan OCB

Hubungan antar variabel dapat digambarkan dalam model sebagai berikut:

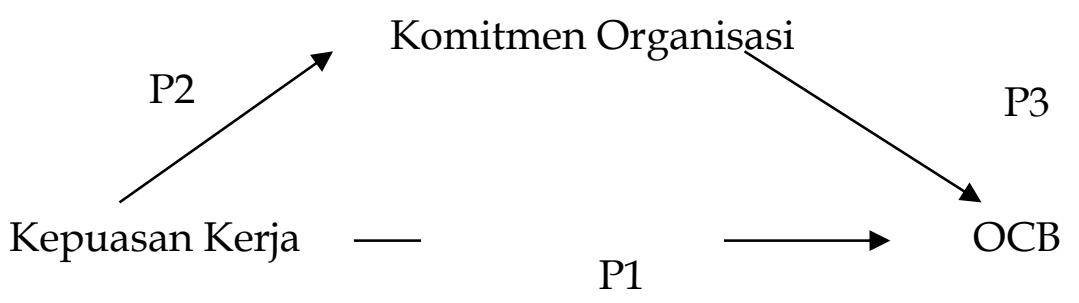

\section{Gambar 1}

Model Penelitian

A. Jenis Penelitian

Jenis penelitian yang digunakan adalah survei. Alat pengumpulan data yang digunakan berupa kuesioner. Teknik analisis data deskriptif dan kuantitatif. 
B. Populasi dan Sampel

Penelitian ini dilaksanakan di Universitas Negeri Yogyakarta pada bulan Juni sampai bulan November 2013. Populasi penelitian ini yaitu karyawan Universitas Negeri Yogyakarta yang berstatus PNS. Teknik pengambilan sampel yang digunakan adalah proportional random sampling. Menurut Sekaran (2003) jumlah sampel 20\% sudah cukup mewakili populasi. Jumlah karyawan UNY per Desember 2012 adalah 565 orang (http://uny.ac.id/profil/statistik-karyawan), sehingga $20 \%$ dari 565 orang adalah 113 orang.

C. Instrumen Penelitian

Pengumpulan data dalam penelitian ini menggunakan kuesioner yang diperoleh langsung dari responden melalui pengisian kuesioner. Kuesioner berisi pertanyaan-pertanyaan mengenai kepuasan kerja yang dikembangkan dari Minnesota Satisfaction Questionnaire, kuesioner komitmen organisasi dikembangkan dari kuesioner Allen dan Mayer (1990), dan kuesioner organizational citizenship behavior dari Organ dan Konovsky (1988). Seluruh variabel dalam penelitian ini diukur dengan menggunakan Skala Likert dengan skala 1 sampai 5. Masing-masing alternatif jawaban akan diberi nilai numerik sebagai berikut: sangat tidak setuju $=1$, tidak setuju $=2$, netral $=3$, setuju $=4$, dan sangat setuju $=5$.

Hasil uji validitas menunjukkan bahwa seluruh butir item pernyataan yang digunakan untuk mengukur variabel kepuasan kerja dan komitmen organisasi valid dan 1 butir item pernyataan untuk mengukur variabel $O C B$ gugur. Sedangkan hasil uji reliabilitas menunjukkan bahwa instrumen reliabel karena memiliki nilai lebih besar dari 0,7 (Nunally dalam Ghozali,2011). Besarnya nilai cronbach alpha kepuasan kerja sebesar 0,94 , komitmen organisasi sebesar 0,86 , dan $O C B$ sebesar 0,87 .

\section{A. Hasil Penelitian}

Teknik analisis data yang dipergunakan dalam penelitian ini adalah analisis jalur (path analysis) dan uji deteksi pengaruh mediasi dengan uji sobel. 1. Analisis Deskriptif 
a. Karakteristik Responden

Komposisi responden berdasarkan jenis kelamin, 79\% berjenis kelamin laki-laki dan $21 \%$ berjenis kelamin perempuan. Hal ini sesuai dengan prosentase karyawan UNY, dimana memang jumlah karyawan laki-laki jauh lebih banyak dibandingkan karyawan perempuan. Berdasarkan tingkat pendidikan, komposisi responden berdasarkan tingkat pendidikan adalah 1\% berpendidikan SD, 2,7\% berpendidikan SMP, 64,5\% berpendidikan SMU, 9,17\% berpendidikan Diploma, dan 22,7\% berpendidikan S1. Komposisi ini sesuai dengan komposisi karyawan UNY yang mayoritas karyawannya berpendidikan SMU.

b. Deskripsi Variabel

Hasil analisis kuesioner variabel kepuasan kerja mendapatkan ratarata jawaban responden untuk variabel kepuasan kerja adalah sebesar 3.7, sehingga masuk kategori tinggi. Untuk variabel komitmen organisasi adalah sebesar 3,9, dan OCB sebesar 3.6. Selain itu, diketahui pula bahwa karyawan karyawan UNY memiliki komitmen normatif dengan rata-rata sebesar 4 , berkelanjutan dengan rata-rata sebesar 3,5, dan afektif dengan rata-rata sebesar 3,2. Untuk variabel $O C B$, rata-rata jawaban responden untuk $O C B$ adalah 3,7. Dengan demikian dapat disimpulkan bahwa karyawan UNY memiliki kepuasan kerja, komitmen organisasi dan OCB yang tinggi.

2. Uji Prasyarat Analisis

Uji prasyarat analisis digunakan agar model penelitian BLUE. Uji prasyarat yang dilakukan adalah uji mormalitas, multikolinearitas, dan uji heterokedastisitas. Berdasarkan hasil uji normalitas data dengan menggunakan uji One-Sample Kolmogorov-Smirnov Test ditunjukkan bahwa data yang digunakan dalam penelitian ini untuk variabel kepuasan kerja, komitmen organisasi dan organizational citizenship behavior adalah normal. Hal ini ditunjukkan dengan nilai Sig Z yang sebesar 54\% Signifikansi tersebut lebih besar dari level of signifikansi 
yang ditetapkan yaitu 5\%, maka dalam hal ini dapat disimpulkan bahwa data tersebut berdistribusi normal.

Uji multikolinearitas dilakukan dengan menganalisis matriks korelasi antar variabel independen dan perhitungan nilai tolerance dan variance inflation factor (VIF). ternyata kolinearitas variabel kepuasan kerja dan komitmen sebesar 0.123 atau 12\%. Oleh karena nilai ini masih di bawah 95\%, maka dapat dikatakan bahwa tidak terjadi multikolinearitas yang serius. Hasil perhitungan menunjukkan tidak ada variabel independen yang memiliki nilai tolerance kurang dari 0.10 yang berarti tidak ada korelasi antar variabel independen yang nilainya lebih dari 95\%. Hasil perhitungan nilai VIF juga menunjukkan bahwa tidak ada variabel independen yang memiliki nilai VIF lebih dari 10. Sehingga dapat disimpulkan bahwa tidak ada multikolinearitas antar variabel independen dalam model regresi.

Uji heteroskedastisitas yang digunakan adalah scatterplot. Dari grafik plot, terlihat bahwa tidak ada pola yang jelas, serta titik-titik menyebar di atas dan di bawah angka 0 pada sumbu $Y$, maka tidak terjadi heterokedastisitas

3. Analisis Jalur

Untuk menguji pengaruh variabel intervening digunakan metode analisis jalur (path analysis). Analisis jalur merupakan perluasan dari analisis regresi linear berganda, atai analisis jalur adalah penggunaan analisis regresi untuk menaksir hubungan kausalitas antar variabel yang telah ditetapkan sebelumnya (Ghozali, 2011).

Dalam penelitian ini ada dua persamaan:

$$
\begin{aligned}
& \text { KO = a + p2Kep.Ker +e1 } \\
& \text { OCВ = a + p1Kep.Ker+p3Kom.Or+e2 }
\end{aligned}
$$

Berdasarkan hasil pengolahan data untuk persamaan pertama dan kedua, dapat diketahui bahwa:nilai unstandardized beta 
kepuasan kerja pada persamaan pertama sebesar 0,482 dan signifikan pada 0.000 yang berarti kepuasan kerja berpengaruh positif dan signifikan terhadap komitmen organisasi. Nilai koefisien unstandardized beta 0,482 merupakan nilai path atau jalur p2. Selain itu, diketahui pula bahwa nilai unstandardized beta kepuasan kerja sebesar 0,147 signifikan pada 0.034 dan komitmen organisasi 0,277 signifikan pada 0,000 . Nilai unstandardized beta kepuasan kerja 0,147 merupakan nilai jalur path $\mathrm{p} 1$ dan nilai unstandardized beta komitmen organisasi 0,277 merupakan nilai jalur path p3. Besarnya nilai $\mathrm{e} 1=\sqrt{1-0,218}=0,782$ dan nilai $\mathrm{e} 2==\sqrt{1-0,265}=0,735$. Analisis jalur model penelitian dapat dilihat pada gambar di bawah ini:

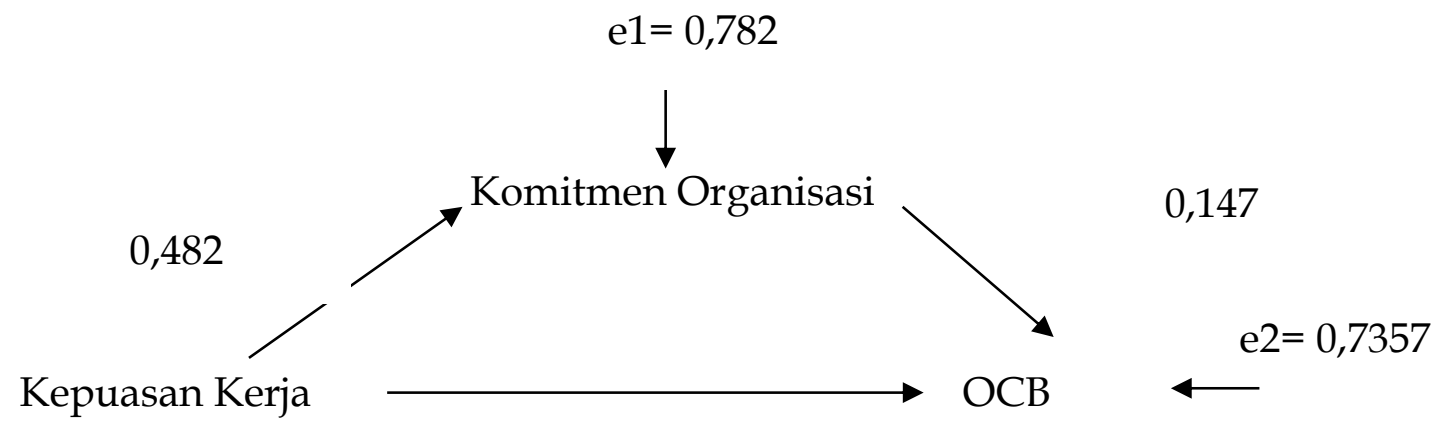

Hasil analisis jalur menunjukkan bahwa kepuasan kerja dapat berpengaruh langsung dan dapat juga berpengaruh secara tidak langsung, yaitu dari kepuasan kerja ke komitmen organisasi. Besarnya pengaruh langsung adalah 0,147, sedangkan pengaruh tidak langsung sebesar 0,1335. Perhitungan total pengaruh dapat dilihat pada perhitungan berikut:
Pengaruh langsung $=0,147$
Pengaruh tidak langsung $=(0,482) \times(0,277) \quad=0,1335$
Total Pengaruh $=0,280514$ 
4. Uji Sobel

Uji sobel digunakan untuk mengetahui besarnya pengaruh mediasi tersebut signifikan atau tidak. Dalam penelitian ini besarnya pengaruh mediasi yang ditunjukkan oleh perkalian p2 dan p3 adalah sebesar 0,1335. Langkah yang dilakukan adalah:

a. Menghitung standar eror dari koefisien indirect effect (Sp2p3), yaitu sebagai berikut:

$$
\begin{aligned}
\mathrm{Sp} 2 \mathrm{p} 3 & =\sqrt{\mathrm{p} 3^{2} \cdot \mathrm{Sp} 2^{2}+\mathrm{p} 2^{2} \cdot \mathrm{Sp}^{2}+\mathrm{Sp}^{2} \cdot \mathrm{Sp} 3^{2}} \\
& =\sqrt{0,0016399256} \\
& =0,0405
\end{aligned}
$$

b. Setelah menemukan standar eror dari koefisien indirect effect, maka langkah selanjutnya adalah menghitung nilai $\mathrm{t}$ statistic pengaruh mediasi dengan rumus sebagai berikut:

$$
t=\frac{\mathrm{p} 2 \mathrm{p} 3}{s p 2 p 3}=\frac{0,1335}{0,04053}=3,2966
$$

Dari perhitungan di atas, diketahui bahwa nilai thitung sebesar 3,2966. Oleh karena nilai t hitung =3,2966 lebih besar dari t tabel dengan tingkat signifikasni 0,05 yaitu sebesar 1,96, maka dapat disimpulkan bahwa koefisien mediasi sebesar 0,1335 signifikan, yang berarti ada pengaruh mediasi komitmen organisasi pada kepuasan kerja terhadap organizational citizenship behavior.

\section{B. Pembahasan Hasil Penelitian}

\section{Pembahasan Hipotesis Pertama}

Hipotesis pertama menyatakan bahwa terdapat pengaruh variabel kepuasan kerja terhadap tingkat $O C B$ yang dialami karyawan Universitas Negeri Yogyakarta. Hasil penelitian menunjukkan bahwa variabel kepuasan kerja memiliki pengaruh yang positif dan signifikan terhadap 
tingkat $O C B$ karyawan sebagai obyek yang digunakan dalam penelitian. Hal ini berarti bahwa hipotesis pertama yang diajukan dalam penelitian ini terdukung dan sekaligus juga mendukung hasil-hasil penelitian sebelumnya yang dilakukan oleh Widyanto, dkk (2013) Dengan demikian kepuasan kerja yang dirasakan oleh karyawan UNY memengaruhi tingkat $O C B$ karyawan.

Kepuasan yang dirasakan oleh karyawan UNY yang berasal berasal dari gaji, promosi, supervisi, rekan kerja, ataupun pekerjaan yang dilakukannya akan memingkatkan OCB. Hal yang sangat penting dan indicator kepuasan kerja adalah pekerjaan itu sendiri. Ketika karyawan merasakan nyaman bekerja atau pekerjaannya mampu mengembangkan potensi yang dimilikinya, dalam arti memberikan tantangan, maka itu menjadi indicator kepuasan kerja baik.

Karyawan UNY yang diteliti dalam penelitian ini adalah karyawan PNS Standar gaji karyawan PNS mengacu standar gaji PNS dengan mengikuti masa kerja berdasar golongan/ruang yang dimiliknya. Standar gaji ini merujuk pada Keputusan Kementrian Pemberdayaan Aparatur Negara.

Peran atasan langsung karyawan sangatlah besar. Di UNY atasan langung karyawan adalah Kepala Sub Bagian (Kasubag) di masing-masing unit. Hubungan yang baik dengan kasubag masing-masing mampu mengindikasikan tingkat kepuasan kerja karyawan UNY.

Setiap karyawan UNY akan mengalami proses rotasi (maksimal setelah bekerja 8 tahun di satu unit). Rotasi yang dilakukan dengan berbagai dari masing-masing Kasubag. Rotasi tersebut salah satunya adalah melakukan promosi jabatan bagi karyawan tersebut.

Hubungan yang harmonis antar karyawan UNY juga baik. Hal ini tentu mengindikasikan bahwa kepuasan kerja karyawan baik. Berbagai kegiatan dilaksanakan oleh masing-masing unit untuk meningkatkan 
keakraban antar karyawan. Kegiatan peningkatan pelayanan prima yang dilakukan setiap setahun sekali bertujuan untuk meningkat pelayanan karyawan terhadap stakeholder. Selain itu, pelatihan outbound yang dilakukan juga mampu meningkatkan kerjasama dan komunikasi antar karyawan.

\section{Pembahasan Hipotesis Kedua}

Hipotesis kedua menyatakan bahwa terdapat pengaruh variabel komitmen organisasi terhadap tingkat $O C B$ yang dialami karyawan Universitas Negeri Yogyakarta. Hasil penelitian menunjukkan bahwa komitmen organisasi memiliki pengaruh terhadap tingkat $O C B$ karyawan sebagai obyek yang digunakan dalam penelitian. Hal ini berarti bahwa hipotesis kedua yang diajukan dalam penelitian ini terdukung. Hasil ini sejalandengan hasil penelitian sebelumnya yang dilakukan oleh Widyanto, dkk (2013) dan Wahyuningsih (2009). Dengan demikian. Komitmen organisasi yang dimiliki oleh karyawan UNY akan meningkatkan OCB.

Dari analisis deskriptif yang telah dilakukan, karyawan UNY merasa memiliki komitmen normatif dan berkelanjutan yang tinggi, dan netral untuk komitmen afektifnya. Komitmen berkelanjutan (continuence commitment) merupakan komitmen berdasarkan kerugian yang berhubungan dengan keluarnya karyawan dari organisasi. Hal ini mungkin karena kehilangan senioritas atas promosi atau benefit. Komitmen normatif (normative commiment) berkaitan dengan perasaan wajib untuk tetap berada dalam organisasi karena memang harus begitu; tindakan tersebut merupakan hal benar yang harus dilakukan, dan komitmen afektif mengacu pada keterikatan emosional, identifikasi serta keterlibatan seorang karyawan pada suatu organisasi. Komitmen afektif seseorang akan menjadi lebih kuat bila pengalamannya dalam suatu 
organisasi konsisten dengan harapan-harapan dan memuaskan kebutuhan dasarnya dan sebaliknya.

\section{Pembahasan Hipotesis Ketiga}

Hipotesis ketiga menyatakan bahwa komitmen organisasi memediasi pengaruh kepuasan kerja terhadap tingkat $O C B$ yang dialami karyawan Universitas Negeri Yogyakarta. Hasil penelitian menunjukkan bahwa komitmen organisasi memediasi pengaruh kepuasan kerja terhadap OCB, hal ini menunjukkan bahwa kepuasan kerja yang dialami oleh karyawan UNY tidak secara langsung mempengaruhi OCB akan tetapi melalui komitmen organisai yang tinggi. Penelitian ini tidak sejalan dengan penelitian yang dilakukan oleh Widyanto, dkk (2013), tapi sejalan dengan penelitian yang dilakukan oleh Sesen dan Basim (2012).

Berdasarkan hasil tersebut, maka kepuasan kerja karyawan UNY berpengaruh secara langsung terhadap OCB maupun dipengaruhi secara tidak langsung melalui komitmen organisasi. Kepuasan yang dirasakan oleh karyawan UNY melalui pekerjaan itu sendiri, gaji, atasan langsung, rekan kerja dan promosi akan berpengaruh langsung terhadap OCB karyawan. Selain itu, komitmen organisasi karyawan UNY menjadi variabel yang memediasi pengaruh kepuasan terhadap OCB karyawan

\section{A. SIMPULAN}

Berdasarkan analisis dan pembahasan terhadap hasil penelitian, maka dapat disimpulkan beberapa hal:

1. Variabel kepuasan kerja dan komitmen organisasi memiliki pengaruh yang positif dan signifikan terhadap variabel kepuasan kerja karyawan UNY.

2. Variabel komitmen organisasi memediasi pengaruh kepuasan kerja dengan OCB karyawan UNY

3. Tingkat kepuasan kerja, komitmen organisasi dan tingkat $O C B$ karyawan UNY masuk dalam kategori tinggi tinggi. 


\section{B. KETERBATASAN}

Keterbatasan penelitian ini adalah bahwa penelitian ini mengambil sampel karyawan UNY yang berstatus PNS. Penelitian selanjutnya diharapkan dapat meniliti seluruh karyawan UNY, baik yang berstatus PNS maupun berstatus lainnya. Selain itu, penelitian selanjutnya dapat mengguji perbedaan tingkat kepuasan kerja dan komitmen organisasi dan $O C B$ dengan melihat jenis kelamin, tingkat pendidikan maupun status kepegawaian, sehingga benar-benar dapat melihat bagaimana kondisi karyawan UNY yang berkaitan dengan variabel tersebut.

\section{SARAN}

Pimpinan UNY hendaknya memberikan stimulus dan motivasi kepada karyawan, sehingga komitmen yang dimiliki oleh karyawan tidak hanya bersifat normatif atau berkelanjutan, tetapi juga komitmen afektif. Beberapa cara yang dapat dilakukan untuk meningkatkan komitmen yang sifatnya afektif adalah dengan memberdayakan karyawan, membangun komunikasi interpersonal yang baik, dan menjamin adanya keadilan dalam organisasi.

\section{DAFTAR PUSTAKA}

Allen, N.J. and Meyer, J.P. (1991), A Three-Component Conceptualization of Organizational Commitment, Human Resource Management Review, Vol 1, No 1, pp. 61-89.

Greenberg, Jerald \& Baron, Robert (2003), Behavior in Organizations, $8^{\text {th }}$ edition, Pearson Education, Inc., Upper Saddle River, New Jersey

Griffin, Ricky W. \& Ebert, Ronald J.(2004), Bussiness Essentials, Prentice Hall Karim, Faisal \& Rehman, Omar (2012), Impact of Job Satisfaction, Perceived Organizational Justice and Employee Empowerment on Organizational Commitment in Semi-Gonverment Orgaization of Pakistan, Journal of Business Studies Quarterly, vol. 3 No. 4, pp 92-104

Krietner, R. \& Kinicki, R (2004), Organizational Behavior, $6^{\text {th }}$ edition, McGrawHill

Lovell, Sharon (1999), Does Gender Affect the Link Between Organizational Citizenship Behavior and Performance Evaluation?. 
http://www.findarticles.com/cf_0/m2294/1999_Sept/58469481/prin t.jhtm

Luthans, F. (2000), Organizational Behavior, New York, Mc GrawHill Organ, D.W., Podsakoff, P.M., and MacKenzie, S.B. (2006), Organizational Citizenship Behavior: Its Nature, Antecedents, and Consequences, SAGE Publications.

Organ, D.W. \& Ryan, K. (1995), A meta-analytic review of attitudinal and dispositional predictors of organizational citizenship behavior, Personnel, Vol 48, No 4, pp. 775-800.

Robbins, S. \& Judge, T. (2007), Organizational Behavior, $12^{\text {th }}$ edition, Prentice Hall

Sekaran, U (2003), Reseach Methods for Bussiness: a Skill Building Approach, John Wiley and Sons, New York

Seniati, L. (2006), Pengaruh masa kerja, trait kepribadian, kepuasan kerja dan iklim psikologis terhadap komitmen organisasi dosen Universitas Indonesia, Makara, Sosial Humaniora, Vol 10, No 2, Desember 2006, 88-97

Sesen, H. dan Basim, N. (2012), Impact of Satisfaction and Commitment on Teacher's Organizational Citizenship, Educational Psychology, Vol 32, No 4, 475-491.

Sloat, Kim (1999), Organizational Citizenship: Does Your Firm Inspire Employees to be "Good Citizens"?, Profesional Safety. April

Widyanto, R., Lau, S.J., Kartika, E.W, (2013), Pengaruh Kepuasan Kerja terhadap Organizational Citizenship behavior Melalui Komitmen Organizational Karyawan Cleaning Service di ISS Surabaya, Journal Hospitality dan Manajemen Jasa, Vol 1 No 1

Schneider, Benjamin \& White, Susan S. 2004. Service Quality: Research Perspective. SAGE Publications.

Sekaran, U. 2003. Research methods for business: A skill building approach. 4th Edition. John Wiley \& Sons, Inc.

Supranto. (2001). Pengukuran Tingkat Kepuasan Pelanggan. Jakarta : PT Rineka Cipta.

Tjiptono, Fandy. (1997). Strategi Pemasaran. Edisi Kedua. Cetakan Pertama. Yogyakarta: Penerbit Andi Offset.

Wijono, Djoko. (1999). Manajemen Mutu Pelayanan Kesehatan Teori Strategi dan Aplikasi. Surabaya : Airlangga University Press.

Winston, William. And Sommers, Paul A. (1999). Consumer Satisfaction in Medical Practice. 1st Edition. Routledge.

Zeithaml, Valarie., Bitner, Mary Jo, and Gremler, Dwayne. (2006). Services Marketing. McGraw-Hill Companies, Incorporated.

Zeithaml, Valarie., Parasuraman, A., and Berry, Leonard L. 1990. Delivering Quality Service: Balancing Customer Perceptions and Expectations. Simon and Schuster.

http://Www. Puskesmas di Banda Aceh Diharapkan Raih ISO. Harian Analisa.htm (Analisa/iranda novandi) Terbit Kamis, 07 Feb 2013 Diakses 5 Maret 2014 
http://www. Analisis Kepuasan Pasien terhadap Pelayanan pada Puskesmas Sungai Durian, Kab.Kubu Raya (Khusnawati, 2010) Diakses 3 Maret 2014 http:/ / www. ISO 9001 : 2008 (Sistem Manajemen Mutu ) berita oleh Herubudiana Diakses 12 Maret 2014

http://www. Profil Puskesmas Mantrijeron ( Dinas Kesehatan Yogyakarta ) Diakses 12 Maret 2014

http:/ / digg.com/d38MASV. Manajemen sistem ISO 9001 : 2008. Diakses 12 Maret 2014

http://Www. Andreas Tri Pamungkas/JIBI/Harian Jogja Edisi Selasa, 26 Juni 2012 Diakses 5 Maret 2014.

http://Www.Dinkes-Diy.Org,. Kesehatan Daerah Istimewa Yogyakarta 2010.com Diakses 3 Maret 2014.

http:/ /Www.Dinkes-Diy.Org,. Kesehatan Daerah Istimewa Yogyakarta 2012.com Diakses 5 Maret 2014.

http://Www.Dinkes-Diy.Org,. Kesehatan Daerah Istimewa Yogyakarta 2005.com Diakses 5 Maret 2014. 